\title{
Land and Legality in the Darfur Conflict
}

\author{
Jon D. Unruh \\ McGill University
}

\begin{abstract}
Land rights in Darfur act as a principal protagonist to the cause and maintenance of the ongoing armed conflict. The internal functioning and interaction of statutory, customary, and Islamic legal regimes regarding land have facilitated significant aspects of the war, and their reform will be fundamental to any effective peace process. This article describes the role of these legalities in the conflict. Subsequent to a description of the legal environment, the article examines the legal crisis regarding land rights, focusing on six aspects: the repercussions of a single law, the exclusionary customary system, profound confusion over concepts and terms, institutional disarray, and the peace accords.
\end{abstract}

\section{INTRODUCTION}

Legal regimes involving land and property rights are a primary contributor to the cause, conduct and maintenance of civil wars. While statutory, customary, and religious legal domains, singularly or in combination, can resolve or manage contentious land and property relations in inclusive ways, they can also severely aggravate ongoing socio-political problems. This aggravation can restrict land access, ownership, and use by some sectors of society while advantaging others; facilitate opposed and confrontational sources of authority over land that are attached to separate constituencies; and can powerfully constrain, threaten or act against acutely felt needs for land and property rights. As well use of legal land regimes in certain ways during conflict can cause and justify a variety of forms of land-related processes of belligerence, such as ethnic cleansing, forced dislocation, secondary occupation, and battlefield gains and losses at different scales. While legal reform involving land rights is virtually universal after wars, this nonetheless is difficult and can fail unless it is known with some precision the role of statutory, customary, and other (i.e. religious) law regarding land in the conflict. This article explores the behavior of these three legal regimes in the land rights issues which have contributed in a primary way to the onset and maintenance of the Darfur conflict. ${ }^{1}$

Land rights in Darfur operate as a central feature of the conflict. Widely regarded as being at the heart of the war, ${ }^{2}$ land rights for the different groups involved in the conflict are highly complex, confused, sensitive, and volatile. ${ }^{3}$ Of the six recognized and agreed upon 'root causes' of the war mentioned in the 2011 peace accord between the government and one set of the primary rebel factions, three deal explicitly with land rights issues. ${ }^{4}$ In one of the most acute manifestations of the land rights problem, certain Arab pastoralists were easily recruited into the Janjaweed for two primary reasons, land and money. ${ }^{5}$ From their perspective, Arab pastoralists of northern Darfur saw an opportunity to correct a long-standing injustice of landlessness caused by the customary, colonial and statutory legal land regimes, by pursuing their acutely felt need for land 
and hence greater political participation in Darfur. Interestingly, Arab pastoralist groups of southern Darfur who already had longstanding and secure claims to large swaths of land based on customary law, attempted to stay neutral in the conflict. At the same time sedentary agriculturalists were (and continue to be) threatened by the increasing numbers of pastoralists and other 'outsiders' who are able to gain access to 'their lands' based on statutory and Islamic law in an increasingly aggressive, confrontational, and secure way. Yet the role of the legal land regimes in the Darfur conflict remains unexamined in the academic literature, even though the relationship between land and armed conflict is well known, and has a significant literature. ${ }^{6}$

Subsequent to a description of the methods used in information gathering for this study, the article briefly describes the legal environment regarding land for statutory, customary, and Islamic law in Darfur. It then examines both the internal operation as well as the interaction of these three sets of law in terms of their misalignment and problematic functioning with regard to each other, and with regard to the on-the-ground realities, expectations, grievances, needs and aspirations for the different populations concerned. In this context six issues are most important, 1) the state's Unregistered Land Act; 2) the exclusion of certain segments of the population from full participation in the hakura customary tenure system; 3) Islamic land law and the different ways it is used; 4) confusion over laws, concepts and terms; 5) land disputes and the dissolution of certain customary institutions; and, 6) problems with the peace accords. While it is beyond the scope of the article to provide an overview of Darfur or the war itself, the article does describe the course of the development of the conflict in terms of legal regime and land rights.

\section{METHODS}

Research was conducted in Darfur and Khartoum in December of 2009 with an in-depth case study. The case study used a mixed method $^{7}$ approach comprising a legal analysis, and qualitative survey of key informant interviews. The mixed method approach is most appropriate

for unstable socio-political settings where a quantitative survey and other forms of sampling that rely on stable populations are not possible. The mixed method approach also facilitates the triangulation of different results, in this case, from the legal analysis, the key informant survey, and the literature review.

An analysis of the relevant Sudanese statutory laws, peace accords, and position statements of the armed factions, along with the academic, NGO, donor, and UN literature was undertaken. As well individual and group interviews totaling 196 people were held in Khartoum and Darfur regarding the history, content, intent, interpretation, application, enforcement, and outcome of customary, Islamic and statutory laws regarding land rights in Darfur. A variety of people and organizations were met with, including government officials at various levels in ministries in Khartoum, Nyala in South Darfur and El Fasher in North Darfur; representatives of the Native Administrations of North and South Darfur; groups of internally displaced persons (IDPs); and officials of UNAMID (the combined UN and African Union Mission in Darfur), the UN line agencies and other international organizations. As well meetings were held with the Darfur Lawyers Association, the Darfur Land Commission, the Shura Council, the Darfur Peace and Reconciliation Council, the Darfur - Darfur Dialogue Committee, academics, and prominent 
individuals and leaders of different tribal groups in North and South Darfur and in Khartoum. These included Paramount Chiefs, Sheiks, local NGOs and tribal elders and religious leaders.

\section{THE LEGAL ENVIRONMENT OF LAND IN DARFUR}

The legal environment in Darfur comprising statutory, customary, and Islamic law has evolved over the course of history in Darfur and Sudan, from different sources and historical developments. While there is overlap between the three approaches to legality in land rights, this involves both forms of congruence, as well as forms of co-option and opposition. But there are also fundamental incompatibilities. The priority of customary law is social stability, saving face and reconciliation of disputes outside of a winner - loser context. Thus customary law in Darfur is about obscuring individual culpability in favor of one's group compensating another or compensating an individual. Formal law on the other hand is concerned with finding and punishing a wrongdoer so as to achieve justice. The issue of evidence is also a fundamental problem for law in Darfur--with statutory law depending on the document and customary law allowing robust use of testimonial and landscape-based evidence. Islamic law as practiced in Darfur allows for yet a different avenue for evidence. ${ }^{8}$ The overall result is that overlapping laws belonging to the different legal regimes actively work at cross purposes, creating significant confusion that exacerbates the war. This section briefly describes these three regimes with regard to land in Darfur.

\section{Relevant statutory laws}

The following Sudanese legislation is thought to constitute the basis for statutory land administration in the country. ${ }^{9}$ Eight laws are briefly described here with regard to their primary characteristics which impact land rights in Darfur. The intent of this sub-section is to provide an overview of the relevant laws, as opposed to an exhaustive description.

The Land Settlement and Registration Act of $1925^{10}$ details how property rights can be acquired through registration, mainly on the basis of occupation in good faith. Customary rights such as those connected to Dar and hakura (described below) in western Sudan are recognized in the law but were never fully incorporated into it. The law was practically applied only in towns and on development schemes and land along the Nile valley, and much less so in the wider rural areas of the country. The law seems to have been derived for the purpose of managing land in areas where it was initially applied, but was nonetheless passed as a national law applicable to all areas of the country. In practice for most of the law's history the government did not interfere in the administration of customary rights in many of the rural areas of the country subsequent to its passage. Thus this law, like others, caused little initial concern or problems for inhabitants of Darfur.

The Land Acquisition Act of $1930^{11}$ provides guidance for the expropriation of land for public purposes. Decision-making for such expropriation is directed to the Council of Ministers, without real possibility for judicial review. The poorly defined concept of what a 'public purpose' really can encompass in the law, seems to constitute a significant basis for interference and expropriation at will. The Act provides for compensation for expropriated lands, either in 
cash or in kind, and any disputes arising through expropriation could be settled by arbitration, but without possibility for a fair appeal.

The Unregistered Land Act of 1970 (ULA) ${ }^{12}$ introduced a dramatic change in both statutory and customary land law. The law stipulated that all land not registered before the enactment of the ULA via the Land Settlement and Registration Act of 1925 became government land, and was deemed to be registered in its name. No proprietary rights could be acquired over such land, only usufructuary rights in the name of individuals. While it was a national law, the ULA was initially not applied to Darfur, because it was intended for the Nile areas, and because Darfur already had the hakura customary tenure system in place. Instead, both the 1925 and 1970 Acts were aimed at the large mechanized agricultural areas along the Nile and the large fertile savanna areas of eastern Sudan. It was only later that they came to be applied to Darfur when it became advantageous for those from outside the region not belonging to the customary hakura tenure system to do so.

The Civil Transactions Act of 198413 partially recognized customary acquisition of land, stating that local communities have usufructuary rights over land they occupy, although legal ownership still remained with the state. This Act reaffirmed that ownership rights to land ultimately resided with government, thus solidifying the subjugated position of customary law and tenure.

The Construction, Planning and Land Disposition Act of 199414 provides details on planning exercises in towns. It includes provisions for the compensation (including in kind) of expropriated land which if implemented would be favorable to landowners. The Act allocates residential town plots on the basis of leases for a fixed term, with possibilities for an extension.

The Emirate Act of $1995^{15}$ was passed by the state of West Darfur to contribute to a larger effort to make the Native Administration more responsive to Arab pastoralists. One result of this law was the division of a large area known as 'Dar Masalit' into 13 estates, five for the native Masalit farmers and eight for the Arab camel herders (who in this area are part of the northern Rezeigat tribe). Prior to this division all the land in Dar Masalit was claimed by the Masalit tribe. The Masalit viewed the division as a way for the Sudanese government to downgrade or abolish their longstanding customary claims to the land. ${ }^{16}$ The Act and the resulting division of Dar Masalit are thought to have played a major role in the armed conflict in 1997 between the Masalit and Arab pastoralists in the area. The recruitment of Masalit youth into the present rebel militias can be linked to the problems over land that the Emirate Act brought about. ${ }^{17}$

The Investment Act of $1998^{18}$ opened the door for the allocation of large tracts of land by central decision-making at the federal and state levels, without consultation with local inhabitants or recognition of their rights. The law built upon the 1970 Unregistered Land Act by allocating land for investment which was owned by government under the 1970 law.

The Local Government Act of $2003^{19}$ devolved some powers regarding land to the locality level, but then reduced the number of localities by 80 percent. A 'commissioner' appointed by the 
President was declared head of the executive branch of each locality, and also head of the five administrative departments within each locality - agriculture; animal and natural resources; finance and planning; health, education and public affairs; and engineering and town planning. By reducing the number of localities, each one was much larger than prior to the Act. The positioning of the commissioner as head of the locality and of the five departments, concentrated decision-making in this position and undermined the role of locally legitimate authorities. The appointment of the commissioner by the President ensured that the priorities of the central state, and not that of local populations would be pursued by the locality administration. The preexisting Native Administration (described below), which traditionally reflected customary and local approaches and priorities regarding land and other issues, was deemed to be part of the locality government and was subverted to the interests of the state by having its authorities now needing to be appointed by state governors and commissioners as opposed to locally selected. As a result some of the Native Administrators and Paramount Chiefs have become so distrusted, that a number of them cannot currently enter IDP camps for fear of being killed.

\section{Customary law and land}

Membership within a tribe that is connected to a specific land area can occur in a nested format in Darfur. The larger form of membership involves connection to a 'Dar', or homeland. As a general rule the Dar is associated with a major tribe or clan, but in practice its residents reflect a wide range of ethnic backgrounds and minority tribes, and smaller Dars exist within larger Dars. The primary advantage of this arrangement for the major tribe is that it gives it a monopoly over the land - political nexus, as well as leadership and revenue collection. Thus Darfur is the Dar or traditional homeland of the Fur tribe. Currently there is a struggle among a number of minority tribes within Dars to obtain their own Nazzirs ${ }^{20}$ and independent Dars, leading to an attempt to separate by some smaller tribes, and the resulting attempt by the larger Dars to keep them from separating. This agitation on the part of the smaller tribes is in part because leadership positions

are also government positions that come with government recognition and benefits. But it is also because the current identity politics in Darfur encourages each tribe to want to be noticed and recognized and not ruled by another tribe.

Darfur's tribes can be classified into land-holding and non-land-holding groups. The first category includes all the sedentary groups plus the cattle-herding tribes of southern Darfur. The second includes the Arab camel nomads of the north and west (including into the Sahara) plus new-comers from neighboring Chad and elsewhere who were either driven by drought and political instability or drawn by opportunity to seek permanent residence in Darfur, or who migrated into Darfur as part of seasonal grazing patterns. The lack of Dars among some groups was partially because the initial granting of tribal Dars in the Sultanate (pre-colonial) era favored the larger sedentary tribes; but also because in the past such land claims were not an important issue for northern Arab pastoralists, whose production system depended on transient instead of permanent rights of land access in order to support nomadic pastoralism and livestock trade. The implications of the distinction between land-holding and non-land-holding groups on the current civil war is of fundamental importance. 
The nested form of membership involves connection to a 'hakura'. While use of the term varies, essentially hakura are forms of land grants or titles given by the Fur sultans to chiefly families, religious figures, or court appointees. These reside within Dars. A hakura exists as a document describing the land grant (including precise boundary definition), but also refers to the land in question itself, which often comprises significantly large areas. ${ }^{21}$ While hakura vary in size, O'Fahey's 22 research into Dar Aba Diima revealed the existence of about 200 hakura in an area of approximately 1500 miles square, resulting in an average hakura size of approximately 70 miles square. Hakura is taken to mean by some as 'tribal land ownership', meaning that the hakura became attached to the area originally occupied by a tribal group. In actuality however the tribe of the original hakura owner (hakura being hereditary) gathered to the hakura and came to occupy and consolidate itself within the hakura. ${ }^{23}$ The rights of the hakura owner were more akin to a feudal jurisdiction, with rights to collect taxes of various kinds, as opposed to a form of freehold. ${ }^{24}$ Currently there is considerable confusion over the term and concept of hakura. Some see it as synonymous with Dar, others view it as a land tenure system belonging to the Fur only, and still others see it as simply a land management system that can be changed or replaced. The various confusing concepts associated with hakura are important to Darfur's current conflict, and will be elaborated upon further below. However a primary narrative is that many Arab pastoralists of the north justify their participation in the current conflict as part of a 250 year-old quest for land that was provided to others but denied to them. This perspective, while not well aligned with actual history, is so acute that "hakura has become a battle-cry of the Janjaweed". ${ }^{25}$

A significant aspect of customary tenure is the 'Native Administration'. Under the colonial policy of indirect rule, tribal leaders were confirmed as part of a Native Administration system and were deemed to be custodians of land belonging to their tribes. Paramount Chiefs, who represent the highest authority in the Native Administration system, performed their duties through a medium level leadership position $(O m d a)$, and the latter through the lower level leadership of a village headman (Sheik). The Paramount Chief was and continues to be responsible for allocating land for settlement and cultivation. Any disputes regarding land rights or natural resources would first be processed through the village Sheik who then communicates with the upper level of the Native Administration to resolve a dispute-with the highest frequency of disputes occurring just before the rains in April when planting is about to commence. Thus the Native Administration provided a system of local governance which managed the use of land and natural resources and facilitated the various groups to live in relative peace. Native Administrators were entrusted with the role of implementing land rights and resource allocation decisions, and regulating the grazing activities of different tribes and outsiders so as to avert conflicts between farmers and pastoralists. This included, the enforcement of boundaries that demarcated grazing and farming areas, regulation of the seasonal movement of pastoralists in terms of timing and routes from their dry season grazing areas to wet season areas, containment and resolution of tribal disputes in the grazing areas, and the opening and closing of water points. ${ }^{26}$ It was unfortunate then that the Sudanese government dissolved the Native Administration in 1971, creating a precarious institutional vacuum; then reinstituted it later but with members selected by government instead of local constituencies. The result is that the Native Administration is now highly distrusted and ineffective. ${ }^{27}$ This crippled much of the 
functionality of the customary tenure system, and did away with the primary avenue for the customary and statutory tenure systems to interface.

Prior to the current war nomadic pastoralists were provided with negotiated transient rights within customary tenure, and these were operationalized through special corridors that passed through the tribal lands of sedentary groups. These corridors were established by arrangements made between the traditional leaders of nomadic and sedentary groups, with the customary rights of each group respected. There also existed an arrangement prior to the war whereby if pastoralist groups wanted to cross from Chad or points north into Darfur they would be linked to a local 'advocate' or sponsor known to the local population, or someone from the incoming pastoralist group that was known locally. Such an advocate would be able to speak for and attest to the good intentions and behavior of the group in question. In this way the pastoralist group would be allowed to stay and negotiate grazing. But benefits from such an arrangement would flow both ways. Because livestock were one of the few ways to store capital, herders were desired by hakura owners. ${ }^{28}$

As a general rule all Dars allowed settlement of newcomers both as individuals and groups, provided that they adhered to the relevant existing customary regulations. Farming, grazing, hunting and forest use were included in such arrangements. Historically it was advantageous for a Paramount Chief or hakura holder to attract newcomers, in order to till the land and provide taxes to the hakura holder. ${ }^{29}$ Agriculturalist newcomers from outside the Dar who wished to farm were usually accommodated within uncultivated 'waste-land' areas or fallow-land, according to local customary norms. If the newcomer was an individual or a few families, they would join an existing village and come under the administrative jurisdiction of its Sheik. However, if the number of newcomers was large enough to constitute a separate village, they were allowed to have their own village and Sheik who would be accountable to the Omda of the area. In such a case the new Sheik would not have jurisdiction over land and so was called 'Sheikh Anfar' (Sheik of people) as opposed to the more powerful and prestigious office of 'Sheikh Al-Ard' (Sheik of the land) which was open only to natives of the Dar.

\section{Islamic law and land}

Islamic law with regard to land rights exists in three general domains in Darfur--as part of statutory law, as part of customary hakura law, and as it functions apart from these in local interpretations.

Islamic law within statutory law

Sudan claims that it is the only country other than Saudi Arabia that uses Sharia law as state law. While this may be the case, not all Sudanese state law is Islamic law. Further, a good number of countries in the Islamic world officially embrace parts of Islamic law as state law, particularly with regard to land rights. During Khartoum's 'Islamization' process in the 1980s, significant components of state law took up various aspects of Islamic law. Of particular interest with regard to land rights is the Civil Transactions Act of 1984, which was issued after parts of Sharia law was enacted as state law. In this law, "land belongs to Allah". From this logic an interpretation is 
then applied to justify state control over land--which is that the state represents the will of Allah and so holds the land in trust for the people, with powers of allocation. Thus the operative notion is that land administration in Sudan is vested in the state to manage on behalf of the Muslim populace. The Act also contains a provision indicating that in the absence of legislation covering an issue, a judge shall apply Shari'a law. ${ }^{30}$ To assist with this there exists a Ministry of Religious Affairs and $W_{a q f}{ }^{31}$.

Islamic law in customary hakura law

Islamic law is fused with customary law in Darfur, as it is throughout the Muslim world. ${ }^{32}$ The historical land documents granting hakura to their original holders in the Sultanate era (the earliest dating from approximately 1700) refer to Allah, the Qur'an, Islamic law, and Islamic precepts throughout. ${ }^{33}$ Some of the land titles (also referred to as deeds or charters) were actual waqf-granting documents (waqfiyya), while many other hakura grants were 'waqf-like' to varying degrees in that they were given to Islamic religious figures and were intended to be continuously held by their descendents, and the deeds given to such figures invoked and used religious phrases and words to different extents. ${ }^{34}$ As a result a particular hakura deed with a significant amount of, or more powerful religious phrasing, would be considered more waqf-like than others which had less religious phrasing. Thus a certain 'argument' in a legal sense, could be made that a particular hakura should be seen as more waqf-like given its phrasing, or mention of certain religious aspects, or the religious figure it was initially given to. Still other land deeds were charters of privilege granted to various holy clans. ${ }^{35}$ Such religious actors were then a primary factor in the further spread of Islam in Darfur. ${ }^{36}$

Islamic law in local interpretations

More localized interpretations of Islamic law or legal precepts regarding land are also evident in Darfur, with one in particular having a significant role in the current conflict. This interpretation begins with invoking, 'all land belongs to Allah' as in statutory law, but instead of proceeding from this interpretation to state control, it follows with 'and is therefore open to any Muslim'. This allows those that invoke this interpretation to simply move onto and claim lands. The interpretation is used as an alternative to the exclusionary aspects of hakura customary law for those not native to a Dar or hakura. Use of this particular interpretation however is confined to specific groups, primarily Arab pastoralists (including the Janjaweed) from north Darfur and adjoining areas of the Sahara, the Zaghawa (agropastoralists and traders) of northwestern Darfur and adjoining countries, as well as other foreigners from Chad and elsewhere. It is not used by the sedentary agriculturalist groups who have prior claim according to hakura law, and who are also Muslim.

\section{THE LEGAL CRISIS IN LAND AND THE ARMED CONFLICT}

From the fieldwork in Sudan six issues emerge as the primary land-related problems which have a large role in the onset and continuation of the Darfur conflict. Three of these are specific to the legal regimes themselves - the repercussions of one Act in statutory law, the characteristic of 'partial inclusion' in customary law, and the facility with which Islamic law can be tailored to specific constituencies. The remaining three are problems that involve aspects of all three legal 
regimes - a deep-seated ambiguity and confusion over important tenurial terms and concepts, the dissolution of specific institutions and the installation of certain replacement institutions in a context of land dispute resolution, and the failure of two peace accords to address crucial landrelated components of the war.

\section{The Unregistered Land Act}

The 1970 Unregistered Land Act stands out as a primary protagonist in the Darfur conflict. When non-native interests (individual, group, and commercial) sought to gain access to lands in Darfur via the 1970 law instead of the hakura system, it became clear that there was never any real opportunity to register land in Darfur according to the 1925 Land Settlement and Registration Act, due to the lack of services for surveying and institutions for registration. Nevertheless in 1970 all unregistered land in Darfur became state land for the state to allocate. Thus the 1970 law asserted government ownership over lands already claimed by the hakura system, and paved the way for subsequent developments regarding land tenure in Darfur which have since contributed significantly to the ongoing nature of the conflict. The potential for using 'guiding principles' within the 1970 Act for recognizing customary land rights acquired through occupation, were rendered meaningless by court decisions and thus a significant opportunity for statutory and customary law to become mutually accommodating was missed. A number of large-scale mechanized agricultural projects, which required large tracts of land with statutory tenure arrangements, have been introduced in southern Darfur (mainly in Um Ajaj) using the 1970 Act. With this Act the government was also able to distribute large plots of farmland to urban merchant elites from outside Darfur (primarily from central and riverine Sudan). This process of land allocation by the state caused considerable animosity among many within the Darfur population. The customary user of unregistered land became completely subjected to the government who could exercise its legal rights at will, thus significantly undermining the ability and authority of customary tenure structures, and decreasing tenure security over customarily held land. And while some local inhabitants now want to register their land to protect it from being reallocated by the state, the government indicates that it is too late, and that they should have registered their land earlier by the time the Unregistered Land Act was enacted.

The lack of opportunity to register land in Darfur according to the Act was not the only problem with the law. Even if there was the possibility of registering land between the 1925 and 1970 Acts and many individuals had done so, it would not have alleviated the animosity that would have emerged when the government moved to officially own and allocate the remaining unoccupied and hence unregistered areas of hakura and Dars. As well, if the farmers would have had the opportunity to register their occupied land, and did, it would have been interpreted as acknowledgement that they concurred with the law that all unoccupied Dar land should rightly go to government; thus there would still have been considerable resistance to the Act. And because under customary law lands are not regarded as property (i.e., a commodity), but are instead a form of homeland, engaging in survey, demarcation and registration based on occupation would have had the effect of converting them to property, allowing government to locate and transact them, thus creating discord. As a result any remedies based on this law, with the presumption that the primary problem was lack of an opportunity to register, will not resolve 
the broader nature of the problem regarding the Act, which is essentially that all land in Darfur is already customarily claimed. In this context those encountered during the fieldwork noted that it is the flexibility and ambiguity of customary tenure, not clarity, that allows for the elasticity needed in the tenure system to accommodate livestock migrations, pursue options in drought years, and importantly allow for local derivation of 'on the spot' solutions to tenure problems as they emerge. All of these are constrained by registration, demarcation and government imposition of statutory laws.

A further disruptive aspect of the law was that Arab pastoralists and Zaghawa newcomers (who occupy different sides in the war) sought to claim land under the law that was not already physically occupied. Historically they respected local customs regarding being 'guests' on others' land, including paying the local Sheik one-third of the crop. But in reaction to the growing prominence of the ULA over time, they started to reason that if the government actually owns the land, why should they pay the local Sheik in order to acknowledge that the land belongs to the hakura system. Further aggravating the situation, was a widely known case whereby a Darfur state governor (appointed by Khartoum) allowed, on his own initiative, an Arab pastoralist group headed by their own Omda to have their own land with no consultation with the local agriculturalist natives, because presumably the government owned the land through the ULA. This has now set a form of precedent, with other nomad groups asking for similar arrangements. Elsewhere migrants from northern Darfur who have settled further southward, have also claimed land rights under the 1970 law, and ignored the hakura approach to guest accommodation for newcomers, instead arguing that such land now belongs to the government, and so can be given to them by the government. Such claims would have been impossible in the past when newcomers were expected to remain as 'guests` of the host tribe and abide by local customary rules regarding land rights. The many conflicts that the resettled Zaghawa have had with the Fur in the eastern $g_{o z}{ }^{37}$, south of El-Fasher in the mid-1980s, were due to the repercussions of the 1970 law. Thus the law asserted government ownership over lands already claimed by the hakura system, allowing outsiders to gain control (in a highly contested manner) over significantly large areas. To this day the legacy of the law's interaction with the hakura system facilitates confrontation between the Fur, the Zaghawa, Arab pastoralists, and government.

\section{Hakura exclusion}

The hakura land system, while historically serving certain groups well, has proved to be exclusionary in important ways for those not native to a Dar that practices the system. This exclusion is partial, but ultimately quite significant and is a fundamental ingredient in the perpetuation of the current conflict. While the system does allow 'outsiders' to enjoy land access, and pursue various production systems, their representation in the political system is limited to the 'Sheik of the people' and at the most the mid-level position of Omda, with both the much coveted 'Sheik of the land' and the higher and more politically powerful position of Nazir (Paramount Chief) unattainable. The ultimate problem with this partial participation in the hakura system is that control over land and political participation are inseparable in Darfur. As well, alliances, loyalties, political gains and the power structures that support these have 
historically been formed around land. ${ }^{38}$ As a result political participation is kept away from the growing communities of migrants, such as the Zaghawa and the Arab pastoralists--whose communities and in many cases wealth (especially for the Zaghawa) have grown considerably over the years. In reaction to the inability of their growing numbers, wealth, and aspirations to politically participate in the areas in which they resided, the communities of newcomers began to demand their own Native Administration, Paramount Chief, and importantly their own hakura. For example arrivals from Chad were given locations in which to live, but as their numbers increased they wanted their own land, and for it to be administered by them. This became a problem because such land would need to be taken permanently away from the original hakura holders. This kind of aspiration became such a widespread issue, that a local conference convened by those native to the hakura system determined that land cannot be given to outsiders if it is taken from those native to the area. And since all land in Darfur is claimed in some way by individuals and groups native to the hakura system, it essentially meant that no land would be available under this construct.

With such partial political participation for the non-natives over time, land tenure insecurity became a serious problem, with the result being that fears about losing land access then drove the search for alternatives to the hakura system--such as statutory law, Islamic law, and forms of resistance and confrontation. Widespread pursuit of these alternatives within hakura administered areas then degraded the hakura system itself, so that it began to have trouble functioning in a cohesive manner. Not surprisingly those native to the hakura system resisted this degradation, also in a confrontational way. Thus what began as a fairly benevolent approach towards 'guests' by those native to the hakura system, changed into a severe problem that has become widely recognized as a primary factor contributing to the persistence of the current armed conflict. The UN-Ocha ${ }^{39}$ in Darfur notes that the hakura system is one of the major stumbling blocks to the peace process, "due in large part because the landless camel herders and to some extent the landless Zaghawa are always against customary law" (author's field notes). In this regard the original hakura granting documents have become a target for destruction by the Janjaweed in the current conflict, in an attempt to reduce the customary legal basis for hakura claims. These documents, once only of historical interest, "today they are weapons of war". 40

The failure to adapt to newly emerging realities on the part of hakura customary law also has had repercussions and points of confrontation with statutory law-which itself has failed to adapt to hakura law. This mutual incompatibility has led to further problems regarding outside investment and the development this has the potential to bring. With no way for such investment (and the needed tenure security for large land areas that this requires) to occur within the hakura system, together with the inability of the statutory system to connect with the hakura system, exclusively statutory approaches were and are pursued in a 'forced' manner instead, because it is what outside investors and government have access to. One study notes that large allocations of land in Darfur have gone to investors from Jordan, Egypt, China, and the Gulf States, as well as Sudanese investors from outside Darfur in this manner. ${ }^{41}$ With the appearance of such outsiders claiming land access via statutory law to large areas within hakura administered lands, 
significant resistance and animosity has emerged on the part of those operating within the hakura system.

A related issue regarding outsiders and land, is the role of hakura law in any potential peace process. In this regard a hypothetical scenario was put to a local Paramount Chief during the fieldwork - 'if the problem outsiders now acting as secondary occupants were de-militarized, and promised to abide by local rules, would they be allowed to stay on unused land according to the old rules of allowing guests onto land?' The answer was an emphatic 'no', under no circumstances would such an arrangement be allowed. This is because good relations are critically important to obtaining land access in the hakura system as an outsider. And since the initial intention of the outsiders was belligerent, such a proposal would not be acceptable under hakura law. The Paramount Chief noted that even within the old hakura title documents it is stated 'do no harm to neighbors', and 'with good neighborly relations', and that such statements are still taken very seriously. Thus arriving in an area in an aggressive manner is the opposite of what is needed to access land. The Paramount Chief noted further that even when an individual or group arrives with good intentions, it usually takes three years of good behavior to obtain firm land rights as guests.

\section{Islamic law problems}

As noted above Islamic law is used in three distinct ways to justify claims to land for three different sectors of society--government, customary (hakura), and Arab pastoralists together with the Zaghawa. Although Islamic scholars agree that according to Islamic law the state can hold land in trust for the universal Muslim community, irrespective of national boundary, it applies only to 'plain land' (in its natural state) as opposed to land that is clearly occupied and used.42 However a primary effect, if not purpose, behind the Sudanese state's use of Islamic law, is to relieve other forms of claim - tribal, autochronous, private, and even that based on customary law which is fused with Islamic law. According to the view of some in Darfur, the purpose of the Ministry of Religious Affairs and Waqf is in fact to co-opt Islamic law and take control of lands away from local people. Alternatively the Arab pastoralist/Zaghawa use of Islamic law to gain land access facilitates dislocating people from lands that are already claimed and used by other Muslims. Both approaches are at odds with lands designated as waqf or waqf-like by the hakura granting deeds. And both approaches seek to discount the establishment of such waqf-the state by no longer honoring the hakura deeds as it once did, and the Janjaweed by attempting to destroy the deeds. Such selectivity regarding use of Islamic law is not new to the conflict. O'Fahey ${ }^{43}$ reports that in 2003 and 2004 the Janjaweed burned mosques, desecrated Qur'ans and killed Imams in an apparent attempt at creating a divide regarding Islam between themselves and the agriculturalists.

Thus these two uses of Islamic law (state and Arab pastoralist/Zaghawa) appear to be set against one another, justifying claims in different ways to separate sets of people. But they also appear to be set against other tenets of Islamic land law regarding waqf, prior claim, ${ }^{44}$ and the approach to using Islamic law in the hakura-granting deeds. 


\section{Confusion over tenurial terms and concepts}

While confusion on a variety of issues is a common element in war-torn societies, it usually does not extend to the common terms and concepts used by the local population to describe and communicate about the land tenure systems they are familiar with, as these pre-date the conflict. This is not the case in Darfur however, where such confusion about the tenure systems is significant, deep-seated, and well predates the conflict. Such that when this combines with a waraffected context, the result can be to add an unusual but substantial tenaciousness to the conflict, because the different understandings of important terms and concepts become readily aligned with different sides in the war in order to support specific narratives, justifications, and historical scenarios.

In Darfur this confusion over land-related terms and concepts exists among all the actors involved, not only among the UN, bilateral donors and NGOs, but also among IDPs, government at different levels, the various armed factions and their constituencies, and civil society itself. With no way to rectify or inform such confusion, important actors work at cross purposes, speculation emerges as a substitute for solid cohesive information, and the overall impact of any peacebuilding activity on land tenure is ultimately less, and potentially damaging. For example, the term hakura is pervasively used, but in a variety of ways. In some cases hakura is referred to as a subset of a Dar and given to a specific person, in other cases hakura is taken to mean the same area as a Dar, while in other cases hakura is more of a system (and not a specific land area) that should be variously reinstated, expanded, done away with, or outlawed, depending on the group (factions, constituency, donors, ethnic groups). Others take hakura to mean a form of ownership rights, although this is not stated in the actual hakura granting documents themselves.

A large part of this confusion over tenure terms and concepts is historical, and has a complex legal aspect. O`Fahey ${ }^{45}$ notes that the language in which the original hakura title documents were written comes from the Maliki School of Law and that this form of legal language can be ambiguous, acting to conceal the underlying fundamental tenure principles in the original land grants. There were as well definitional problems regarding, 1) translating the documents into English legal language in the colonial and independence periods, 2) assumptions by the translators regarding the static nature of the tenure system, 3) influence by British tenure concepts, and 4) the fact that the legal terminology used in the original charters had their origin in societies that were irrigation-based, making interpretation with regard to oral history difficult. ${ }^{46}$ In addition, information about many hakura exist as narratives, which are often subjective and contradictory, particularly regarding how many there are, where they are, and what the boundaries are. ${ }^{47}$ This becomes still more problematic given that many hakura documents have been destroyed in the war. While these issues may seem overly nuanced in the context of the severity of the ongoing conflict, they are of fundamental importance due to the confusion produced, the multiple interpretations this has allowed, and the alignment of the different interpretations to different sides in the war, such that they have become "a deadly living issue in today`s Darfur". ${ }^{48}$ One interpretation that has solidified among some sectors (i.e. certain segments of civil society, international community, some actors in the peace process) is that hakura is equated to a form of freehold, and hence non-negotiable and therefore immutable, 
while in reality research into the issue has demonstrated that hakura ultimately always likely belonged to the Sultan who granted them. ${ }^{49}$ In this context then what was and is to be the legal fate of such lands after the demise of the Sultanate period? With no legal or widely agreed upon understanding regarding the transfer of land to grantees, occupants, colonial or independence governments or others, the issue is open to varying interpretations, arguments, and claim. Regardless of how the land issues in Darfur proceed, how the various ideas of hakura are dealt with will play a large role. Not only does hakura need a common definition, but as well any other definitions, while technically incorrect, also need defining as to what is being described, given their role in the current narratives of the different groups.

Statutory law with regard to Darfur is also confused, in particular with regard to the tenure concepts and definitions of hakura, tribal land, private property, Dar, and the 'property' versus 'administrative' nature of statutory and customary boundaries. As well there is ongoing confusion and incongruence with regard to the relevance of laws, the history of their application or not, and who they applied to and why. For example the 2005 Constitution states that traditional lands are recognized as such and owners must be compensated if the land is taken by government. But this is largely ignored both in practice and in various laws. The result is considerable ambiguity and animosity regarding who is and was able to use which laws and in what way to gain access to land, and exclude others.

\section{Land disputes, Native Administration and the 'land sheik'}

A primary manifestation of the legal incompatibility regarding land in Darfur was the inability to resolve land disputes, and the subsequent aggravation of these over time into violent trends. When the major droughts hit the region in the $1970 \mathrm{~s}^{50}$ and pastoral groups started to move south into the Jebel Mara area, serious land conflicts with the local sedentary groups emerged. With the government's dissolution of the Native Administration in 1971 (which operated the land conflict resolution institutions), and no effective, locally legitimate institutions to replace it, claimants resorted to violence to deal with disputes. While in-group dispute resolution mechanisms such as the judiya, and dispute resolution through local Sheiks by and large were able to continue to work on their own - attesting to their resilience--this occurred (and continues) only at the local level between those of the same tribal affiliation. But this was not the case when the dispute involved people over larger areas or between tribes, or pastoralist vs. agriculturalist groups. Such larger scale disputes became unresolvable in the absence of an effective Native Administration, and turned acute, feeding into the developing narratives of injustice, victimization, and retribution which aligned with different sides in the current conflict. In place of such mechanisms many groups and individuals attempted to pursue (apart from violence) dispute resolution within statutory law, and forms of Islamic law. However these suffer from interpretation, enforcement, compatibility and personnel problems, and in the case of statutory law, legitimacy problems. This led to a situation of 'forum shopping' for land dispute resolution mechanisms among the incompatible sets of law. While this could be beneficial for disputants who agree on a single fora, for the more volatile group-based disputes, attachment to different fora became part of the larger tribal political problem. ${ }^{51}$ 
A significant dimension of the land dispute problem exists between IDPs and secondary occupants (constituencies to the Janjaweed) currently on IDP land who believe they have government permission to keep lands they have 'liberated'. Certain organizations with experience in Darfur believe that one reason the government is reluctant to address the current land disputes between IDPs and secondary occupants is that the longer secondary occupants reside on the land, the more 'legal` such occupation can potentially become. Some of the secondary occupants even claim to have documents for the land they occupy. Part of such a position by government would be, that to now decide (and enforce) that secondary occupants could no longer keep 'liberated lands', would undoubtedly mean greater trouble with Arab pastoralist groups at a time when such relations are already quite problematic. It is also arguably a reason why government wants many IDPs to go to 'model villages' in alternative locations, or in other cases have residential plots given to them in and around towns. Certain events would seem to support this. On occasions when IDPs refuse to return to their areas of origin until the secondary occupants are removed, the government opts to move the IDPs to urban housing as opposed to removing the secondary occupants. From the fieldwork some secondary occupants say that many of the IDPs won't return to their lands, providing them with an additional argument to claim such land. While forms of land sharing between IDPs and secondary occupants have been suggested, the local NGO Ajaweed asserts that righting past wrongs, and compensation for damages and losses will need to come before any issues of land sharing arrangements can be considered. ${ }^{52} \mathrm{~A}$ significant complication however is that the conflict, displacement, and environmental degradation has meant that there has been large-scale removal of important landscape features which serve as customary forms of evidence for claim, such live boundaries, large trees and other visible forms of demarcation..$^{53}$

An additional important cause of land disputes has resulted from a change in the duties of the 'land sheik'. The land sheiks were important in the rainfed areas and had a number of responsibilities, including negotiation with nomads regarding the timing of the use of livestock migration routes through the cultivated areas. But perhaps the most important issue for the land Sheiks was to manage the timing and use of the post-harvest fields for grazing while livestock were progressing through the migration routes. Historically the land sheik would inform local farmers of the date by which they needed to have their harvested crops and possessions out of their fields, otherwise they could not complain about any livestock damage that might occur. This was an important role because in different years and in different areas, crops would be harvested at different times. However in 1990 the government bypassed the land Sheiks, and simply announced the date by which livestock would be allowed into rain fed crop areas Darfurwide. This occurred without negotiation between farmers and herders, or an appreciation of the variation in harvest times across space and time or the role of the land Sheiks. The position of the land Sheik was thus undermined significantly. In many areas this meant that livestock entered cultivated areas prior to harvest and destroyed crops. The reason for the government intervention appears to have been that in years of drought some areas were congested with livestock waiting to enter post-harvest fields, and pastoralists asked farmers to harvest quickly so as to allow grazing. Some pastoralists complained to government about the timing and access problem, and also claimed that farmers were expanding their cultivated areas. As a result the government 
decided on its own calendar as to when pastoralists could enter cropped lands, instead of supporting the negotiated approach of the land Sheiks. This weakened the flexibility of customary tenure and its ability to manage relationships in a stable manner between agriculturalist and pastoral groups. The farmers reacted to this government intervention and the large increase in crop damage, especially near Jebel Mara where rainfed crops are harvested later (and where the war began), by burning the bush grazing areas around their crops so as to discourage entry into the overall area by pastoralists. The nomads then reacted by taking their herds directly into the unharvested standing crops to graze, and burning farming villages. The farmers then reacted to this by killing livestock.

Cases of crop damage in the past had the nomad and farmer in question going to a Native Court headed by a Paramount Chief to negotiate damage payment. But with the new government calendar the nomads no longer felt obliged to go to these courts or negotiate for damage payments, further undermining the customary tenure system and aggravating relations between the two groups. This meant that if a farmer wanted to get damage payment for his crops he would need to go to a statutory court, which was expensive, and where statutory law meant that a different burden of proof was needed. Farmers regarded such courts as pro-Arab pastoralist and so did not engage them. With no widely legitimate institutional way to resolve such problems, farmers instead began to burn more grazing areas, arm themselves, and take matters into their own hands. The pastoralists then armed themselves in response.

\section{CONCLUSION - THE PEACE ACCORDS}

There is nothing about land-related statutory law, customary law, and Islamic law per se in Sudan that prevents them from interacting in ways that are compatible, responsive, and stable. However it requires purposeful attention, and in Darfur this has not developed. Instead the interaction between the three sets of law have developed in a mutually antagonistic way, and the two peace accords presently in place do little to resolve this. In conclusion this article turns to these accords - the 2006 Darfur Peace Agreement (DPA), and the 2011 Doha Document for Peace in Darfur (DDPD) - in order to highlight important deficiencies. While both agreements deal extensively with land issues, both in reality are well beyond the organizational, technical, financial, political, and legal capacity of the current actors in Darfur to achieve without significant, sustained external support regarded as legitimate and objective by all parties. As a result real opportunities languish and the outcome is poor. Both agreements are lacking a primary consideration fundamental to durable peace - the inclusion of the land issues important to Arab pastoralist groups and the legal constraints and opportunities in statutory, customary, and Islamic law that are important to these issues. There is no mention of Darfur Arab groups in either agreement, and in a particularly glaring omission no mention of the specific land issues which had a large role in their armed mobilization and the ease with which the Janjaweed was created. As well both agreements lack an acknowledgement of, much less an effective approach to resolve, the Darfur specific relationships between the inability of IDPs to return to areas of origin, and a significantly large secondary occupation on those lands by individuals and groups who are constituents of Arab militias and who believe they were given a form of permission to occupy such lands. Thus both agreements fail to realize that in order to deal with land issues for IDPs, 
they must also deal with land issues faced by Arab pastoralist groups. In both cases the latter were not invited or included in the negotiations or agreements. While a delegation did attempt to join the negotiations in Abuja in October of 2005 to communicate that their interests were not being addressed, they were prohibited from participating. ${ }^{54}$ Given how interwoven these two sets of land issues are in Darfur, dealing with one and not the other has a low probability of success.

Both peace agreements recognize the reinstitution of an unreformed hakura system, which the Arab pastoralist groups, the Zaghawa, and those practicing statutory law have great interest in ether reforming or doing away with; thus provoking their resistance and noncompliance. The DPA was particularly remiss in taking pastoralists into account. Pastoralism is noted on only one page of the entire agreement and only with regard to there being a problem in competition for pasture. 55 There was no acknowledgement of the nomadic migratory land issues which in the past had been viable. The 2011 Doha agreement mentions pastoralist land access, but again treats land issues for pastoralists as one of grazing and watering access needs only, and does not address the problem of not being able to participate in the hakura system as equals. That the 2006 DPA committed the government to "neutralize and disarm the Janjaweed /armed militias" only served to aggravate matters from the Arab pastoralist perspective, in that their primary route to gaining or maintaining land rights continues to be through violence. The DPA committed government to institute a process to "develop and amend the relevant laws to incorporate customary laws, practices, international trends and practices..." and further indicates, "all displaced persons and other persons arbitrarily or unlawfully deprived of rights to land shall have those rights restored to them," 56 but neither has occurred. And while there was instituted a Darfur Land Commission ${ }^{57}$ its activities are minor and ignored by government, rendering it ineffective and falling far short of its mandate.

Resolving the definitional dilemma at this point in the conflict will not be easy, as the ambiguous, divergent and confrontational understandings of important terms and concepts are now an intrinsic part of the conflict. With different definitions of the same terms operative, discussion regarding the land issue is very difficult, as would be any negotiations on land issues or their durable solutions. The two accords do not improve matters in this regard, and in fact seem unaware of the issue, such that it remains unaddressed, and so continues to have a role in sustaining the conflict.

Bringing an end to the Darfur conflict will be a significant challenge, and as both peace accords attest, the role of law and legalities regarding land will be heavily relied upon. While the mechanics of statutory land policy reform after conflicts are well known, less obvious is how to align and link it effectively to customary and Islamic law given that these are now used in confrontational ways in the conflict. In hindsight a couple of questions are brought to the fore. Would hakura land tenure have been able to adapt to the growing land/political aspirations of outsiders if the state had not done away with or compromised important customary institutions? If statutory law had supported an interface with hakura law in adaptive ways, would there have been less problems involving the legal regimes and outsiders, including investors? 
At present the three different legal regimes operative in Darfur have come to be set against one another, with overlapping laws resulting in confusion and a substantial aggravation of the conflict. Because of this legal confusion (including the confusion over terms and concepts), different interests in Darfur are able to use laws, traditions, and religion opportunistically to advance specific agendas within the conflict. One unfortunate consequence is that the three legal regimes have been delegitimized thus making it significantly problematic to attempt to resolve important issues using these regimes.

What is required at this point is significant legal innovation, as opposed to relying on attempts to reinstate laws, legal regimes and legal understandings that have now become part of perpetuating the conflict. In this regard examples exist where tools and concepts in legal pluralism ${ }^{58}$, use of 'points of compatibility' between different (even opposed) laws and legal regimes, ${ }^{59}$ legal reform involving robust consultation, ${ }^{60}$ innovative forms of restitution, ${ }^{61}$ and purposeful 'management' of the ambiguity inherent in conflict scenarios ${ }^{62}$ can be productively used.

\section{End Notes}

${ }^{1}$ In this case the onset and continuation of conflict is meant to be the presence of armed conflict, as opposed to the amount of violence or other measures of conflict.

2 Julie Flint, and Alex De Waal, Darfur: A New History of a Long War (London: Zed Books, 2008); Draft Darfur Peace Document (DDPD), Draft Darfur Peace Document (Doha, Qatar, 2011); Tajeldin Abdhalla, Land Rights Confusion Hinders Darfur IDP Returns, Institute for War and Peace Reporting, ACR Issue 237 (2010a); Sara Pantuliano, The Land Question: Sudan's Peace Nemesis, Humanitarian Policy Group (London: Overseas Development Institute, 2007); Osman Suiliman, The Darfur Conflict: Geography or Institutions? (New York: Routledge Press, 2011); Jerome Tubiana, "Darfur: A War of Land?" in: War in Darfur and the Search for Peace, eds. Alex De Wall (Cambridge: Harvard University Press, 2007); Musa Adam Abdul-Jalil, "Intertribal Conflicts in Darfur: Scarcity of Resources or Crises of Governance?" in Environment and Conflict in Africa: Reflections from Darfur, eds. Marcel Laroy (Addis Ababa: University for Peace, Africa Programme, 2009); Omer Egemi, Land Tenure Issues in Darfur (Nairobi: UN Habitat, 2009).

3 Julie Flint and Alex De Waal, Darfur: A New History of a Long War (London: Zed Books, 2008); Musa Adam Abdul-Jalil, "Land Tenure, Land Use and Inter-Ethnic Conflict in Darfur," in Understanding the Crisis in Darfur: Listening to Sudanese Voices, eds. Abdel Ahmed and Leif Manger (Bergen, Norway: University of Bergen, 2007); Osman Suiliman, The Darfur Conflict: Geography or Institutions? (New York: Routledge Press, 2011); Concordis, Land Use and Tenure: A Key to Sustainable Peace in Darfur (Cambridge: Concordis Papers, 2007).

${ }^{4}$ Draft Darfur Peace Document (DDPD), Draft Darfur Peace Document (Doha: 2011).

5 Julie Flint, Beyond 'Janjaweed': Understanding the Militias of Darfur, Small Arms Survey (Geneva: Graduate Institute of International and Development Studies, 2009). 
${ }^{6}$ For example, Karl Polanyi, The Great Transformation: The Political and Economic Origins of Our Time (Boston: Beacon Press, 1957); Jon Unruh, "Land Rights and Peacebuilding:

Challenges and Responses," International Journal of Peace Studies 15, (2011): 89-125; Carl Bruch, David Jensen, Mikiyasu. Nakayama, Jon Unruh, Rebecca Gruby, and Ross Wolfarth, "Post-Conflict Peacebuilding and Natural Resources," Yearbook of International Environmental Law 19 (2009): 58-96; Alexander Murphy, "Historical Justifications for Territorial Claims," Annals of the Association of American Geographers 80 (1990): 531-548.

7 Jennifer Greene, Valerie Caracelli, and Wendy Graham, "Toward A Conceptual Framework for Mixed-Method Evaluation Designs," Educational Evaluation and Policy Analysis 11, no 3 (1989): 255-274.

${ }^{8}$ In Darfur a claimant can ask an Islamic judge to have the person suspected of committing the act in question (i.e. damage to land, land and property disputes, etc.), swear on a Qur'an that he is innocent. If the Qur'an is a mass produced printed copy then the exercise is much less powerful than if the Qur'an is old, hand written, has a long religious history attached to it, was written from memory by a famous religious person known in history or who made the Haj, and is kept in a mosque. With the latter, the exercise is much more powerful because to lie while swearing an oath on such a Qur'an is thought to bring calamity.

9 Paul De Wit, Massimiliano Bellini, Jeffery Hatcher, and Mohammed Hassan Mukhtar, Land Policy Report for DJAM (Rome: UN Food and Agriculture Organization, 2008).

10 Government of Sudan (GOS), The Unregistered Land Act (Khartoum: Ministry of Justice, 1970).

11 Government of Sudan (GOS), The Land Acquisition Act of 1930 (Khartoum: Ministry of Justice, 1930).

12 Government of Sudan (GOS), The Unregistered Land Act (Khartoum: Ministry of Justice, 1970).

${ }^{13}$ Government of Sudan (GOS), The Civil Transactions Act (Khartoum: Ministry of Justice, 1984).

14 Government of Sudan (GOS), The Construction, Planning and Land Disposition Act (Khartoum: Ministry of Justice, 1994).

15 Government of Sudan (GOS), The Emirate Act of 1995 (Khartoum: Ministry of Justice, 1995). ${ }_{16}$ Musa Adam Abdul-Jalil and Zahir. Abdal-Kareem, Contested Land Rights and Ethnic Conflict in Mornei, West Darfur: Scarcity of Resources or Crises of Governance? (Khartoum: University of Khartoum, 2011).

17 Musa Adam Abdul-Jalil, and Zahir Abdal-Kareem, Contested Land Rights and Ethnic Conflict in Mornei, West Darfur: Scarcity of Resources or Crises of Governance? Unpublished Manuscript, (Khartoum: University of Khartoum, 2011). 
18 Government of Sudan (GOS), "The Investment Act” (Khartoum, Ministry of Justice, 1998).

${ }^{19}$ Government of Sudan (GOS), The Local Government Act of 2003 (Khartoum: Ministry of Justice, 2003).

${ }^{20} \mathrm{~A}$ Nazzir is a high level position with control over land. In some interpretations a Nazzir is equivalent to a Paramount Chief

${ }^{21}$ Rex O'Fahey, and M. Abu Salim, Land in Dar Fur: Charters and Related Documents from the Dar Fur Sultanate (Cambridge: Cambridge University Press, 2003).

${ }^{22}$ Rex O'Fahey, The Darfur Sultanate: A History (New York: Columbia University Press, 2008).

23 Julie Flint, and Alex De Waal, Darfur: A New History of a Long War (London: Zed Books, 2008).

24 Julie Flint and Alex De Waal, Darfur: A New History of a Long War (London: Zed Books, 2008).

${ }^{25}$ Rex O'Fahey, The Darfur Sultanate: A History (New York: Columbia University Press, 2008:136).

${ }^{26}$ Musa Adam Abdul-Jalil, "Land Tenure, Land Use and Inter-Ethnic Conflict in Darfur," in Understanding the Crisis in Darfur: Listening to Sudanese Voices, eds. A. Ahmed and L. Manger (Bergen, Norway: University of Bergen, 2007).

27 Abdelgalil Elmekki, DDDC Common Ground Consultations and Public Hearings, (Khartoum: Darfur - Darfur Dialogue and Consultation (DDDC), 2009).

${ }^{28}$ Rex O'Fahey, The Darfur Sultanate: A History (New York: Columbia University Press, 2008).

${ }^{29}$ Rex O'Fahey, The Darfur Sultanate: A History (New York: Columbia University Press, 2008).

${ }^{30}$ Carey Gordon, "Recent Developments in the Land Law of the Sudan: A Legislative Analysis," Journal of African Law 30 (1986):143-174.

${ }^{31}$ A waqf is an Islamic law religious endowment of land or property, and is regarded as inalienable. Most often created for charitable purposes, waqf can exist in a variety of forms, and are influenced by local political, economic, and social conditions (Sait and Lim 2006). Sait and Lim (2006) provide a succinct definition, " $[u]$ nder the waqf, an owner permanently settles property, its usufruct or income, to the use of beneficiaries for specific purposes."

32 Siraj Sait, and Hilary Lim, Land, Law, and Islam: Property and Human Rights in the Muslim World (London: Zed Books, 2006); James Anderson, Islamic Law in Africa (London: Frank Cass and Co. LTD, 1970); John Bowen, Islam, Law and Equality in Indonesia: An Anthropology of Public Reasoning (Cambridge: Cambridge University Press, 2003); Satish Ganjoo, Economic System in Islam (New Delhi: Amnol Publications LTD, 2004); Erein Stiles, An Islamic Court in Context: An Ethnographic Study of Judicial Reasoning (New York: Palgrave Macmillan, 2009). 
${ }^{33}$ Rex O'Fahey, and M. Abu Salim, Land in Dar Fur: Charters and Related Documents from the Dar Fur Sultanate (Cambridge: Cambridge University Press, 2003).

34 Rex. O'Fahey, and M. Abu Salim, Land in Dar Fur: Charters and Related Documents from the Dar Fur Sultanate (Cambridge: Cambridge University Press, 2003).

35 Rex O'Fahey, and M. Abu Salim, Land in Dar Fur: Charters and Related Documents from the Dar Fur Sultanate (Cambridge: Cambridge University Press, 2003).

36 Rex O'Fahey, The Darfur Sultanate: A History (New York: Columbia University Press, 2008).

${ }^{37} \mathrm{Goz}$ are areas of stabilized sand dunes that are preferred for agriculture.

38 Omer Egemi, Land Tenure Issues in Darfur (Nairobi: UN Habitat, 2009).

39 The United Nations Office for the Coordination of Humanitarian Affairs

40 Rex O'Fahey, The Darfur Sultanate: A History (New York: Columbia University Press, 2008:136).

41 Sara Pantuliano, The Land Question: Sudan's Peace Nemesis. Humanitarian Policy Group (London: Overseas Development Institute, 2007).

42 Siraj Sait, and Hilary Lim, Land, Law, and Islam: Property and Human Rights in the Muslim World (London: Zed Books, 2006).

${ }^{43}$ Rex O'Fahey, The Darfur Sultanate: A History (New York: Columbia University Press, 2008).

44 Siraj Sait, and Hilary Lim, Land, Law, and Islam: Property and Human Rights in the Muslim World (London: Zed Books, 2006).

45 Rex O’Fahey, The Darfur Sultanate: A History (New York: Columbia University Press, 2008).

46 Rex O'Fahey, The Darfur Sultanate: A History (New York: Columbia University Press, 2008).

47 Omer Egemi, Land Tenure Issues in Darfur (Nairobi: UN Habitat, 2009).

48 Rex O'Fahey, The Darfur Sultanate: A History (New York: Columbia University Press, 2008:134).

${ }^{49}$ Rex O’Fahey, The Darfur Sultanate: A History (New York: Columbia University Press, 2008).

50 Marcel Leroy, Environment and Conflict in Africa: Reflections on Darfur (Addis Ababa:

University for Peace, 2009). 
51 To help address such disputes, during the current conflict a local NGO, 'Ajaweed' (meaning 'group of elders'), was started, with one of its purposes being to minimize involvement by government in dispute resolution, because according to them, when government gets involved the conflict often gets worse. Ajaweed notes that interaction with government by conflicting parties usually results in failure of dispute resolution and an impasse.

52 One approach suggested by Ajaweed is that the Council of Tribes handle specific cases and decide on compensation by one tribe to another. The tribe to pay then obtains money from each tribal member and can pay the other tribe in installments. Another suggested strategy is for a tribe to forgive a specific occurrence of violence and forgo compensation, which then obligates the other tribe to not attack them in the future. Such arrangements have occurred in the past.

${ }^{53}$ Omer Egemi, Land Tenure Issues in Darfur (Nairobi: UN Habitat, 2009).

${ }^{54}$ National Peace and Development Forum (NPDF), An Application to Join the Ongoing Peace Talks in Abuja, National Peace and Development Forum (unpublished manuscript, 2005).

55 Julie Flint, Beyond 'Janjaweed': Understanding the Militias of Darfur, Small Arms Survey (Geneva: Graduate Institute of International and Development Studies, 2009).

56 Darfur Peace Agreement (DPA), Darfur Peace Agreement: article 20 (Abuja: Nigeria, 2005).

57 Darfur Land Commission (DLC), Conceptual Framework, Darfur Land Commission (Khartoum: Transitional Darfur Regional Authority, 2007).

58 See for example, Jon Unruh, "Land Tenure and Legal Pluralism in the Peace Process," Peace and Change: A Journal of Peace Research 28 (2003): 352-376.

59 For example see, Ade Renner-Thomas, Land Tenure in Sierra Leone: The Law, Dualism and the Making of a Land Policy (London: Author House Press, 2010).

60 See for Example, Mohamed Foray, Draft national Land Policy for Sierra Leone, National Land Policy Reform Project (Freetown: Ministry of Lands, Country Planning and the Environment, 2011).

${ }^{61}$ Colombia has among the most innovative forms of restitution, see, Ministerio de Agricultura $\mathrm{y}$ Desarrollo Rural, La Restitucion de Tierras si es Possible en Colombia (Bogota: Ministerio de Agricultura y Desarrollo Rural, 2010).

62 Jon Unruh, Constituencies of Conflict: Land Rights, Narratives, and Legal Pluralism in Darfur (Cape Town: Presented at the Commission on Legal Pluralism Conference, 8 - 10 September 2011, University of Cape Town, South Africa). 